\title{
CARTOGRAPHIES OF ACTION RESEARCH: SEARCHING FOR DISPLACEMENTS OF THE EPISTEMOLOGY OF THE SOUTH ${ }^{1}$
}

\author{
Lumárya Souza de Sousa \& Thaiane Oliveira
}

\begin{abstract}
The purpose of this paper is to discuss action research as one of the possibilities for the development of an epistemology of the South, in which scientific knowledge and other ecologies of knowledge can be linked. In this work, we propose a mapping of what has been developed on action research in Brazil, seeking to discuss this dimension of knowledge production from perspectives which seek to break the gap between colonizing and invisibilized science in the geopolitics of scientific knowledge. Thus, our proposal seeks to answer what has been produced on action research in Brazil, who are the actors that are developing this type of research and how it can be understood as belonging to an epistemology of the South.
\end{abstract}

KEYwORDS

Action research; epistemology of the South; invisible science; Global South

\begin{abstract}
Resumo
A proposta deste trabalho é discutir sobre a pesquisa-ação como uma das possibilidades de desenvolvimento de uma epistemologia do Sul, na qual possa se atrelar o conhecimento científico e outras ecologias de saberes. Propomos, neste trabalho, realizar uma cartografia sobre o que vem sendo desenvolvido sobre pesquisa-ação no Brasil, buscando discutir esta dimensão de produção de conhecimento a partir de perspectivas que busquem romper o abismo entre ciência colonizadora e a ciência invisibilizada na geopolítica do conhecimento científico. Assim, nossa proposta busca compreender o que vem sido produzido sobre pesquisa-ação no Brasil, quem são os atores que estão desenvolvendo este tipo de pesquisa e como esta pode ser entendida como própria de uma epistemologia do Sul.
\end{abstract}

\section{INTRODUCTION}

Scientific production is based not only on institutional imperative norms, as already pointed out in the 1940 s by Robert Merton (1972), on the modern science assumptions, in which the scientific research results belong to the society in its entirety, but also involves several disputes regarding capital and power to subdue the places, in

\footnotetext{
' Supported by DAAD with funds from the German Federal Ministry for Education and Research (BMBF), related to an international cooperation with Tubingen University on Literacies of Global South.
} 
which the global scientific knowledge circulates ${ }^{2}$. The sociologist, even in the first half of the twentieth century, recognized that such norms were not imperative, and that a series of other symbolic vanities and capitals directly affect the scientific ethos (Merton, 1968). However, rather than internal dynamics of social micro-organizations and symbolic capital disputes, the scientific ecosystem is also consolidated by economic capital disputes in the geopolitics of knowledge based on the trade of knowledge.

In this scientific ecosystem, we might observe the predominance of a group of publishing companies that create norms towards the quality of scientific knowledge, forming an oligopoly in which its profit is based on the trade of knowledge (Larivière, Haustein \& Mongeon, 2015) and thus give an hegemonic status to a group of countries that have been dominating the scientific knowledge market for more than 350 years.

In this scientific ecosystem there is an abyssal gap (Santos, 2007) between what is hegemonic and what is peripheral, between what is visible and what is being made invisible, reinforcing the idea that different circuits of scientific knowledge production coexist. Moreover, other dichotomies are developed around modern science based on the legitimacy of the knowledge production based on rationalism and distinguishing scientific and popular knowledge, thus creating barriers that separate whether the knowledge is validated by science and what is not. Therefore, it is necessary to develop forms of thought that seek to overcome these dichotomies of scientific circulation, allowing the overcoming of these distinctions of the production of different knowledge, something that could only come from the post-abyssal thinking (Santos, 2007).

According to Maria Paula Meneses (2008, p. 5), based on the writings of Boaventura de Sousa Santos (1995, 1999, 2000, 2007, 2008, among others), which since 1995 has been proposing an approach on the issue, "the epistemology of the South is based on three guidelines: learning that there is a South; learn how to go to the South; learn from the South and with the South". These authors believe that the radical separation in a hierarchy of types of knowledge attributed to modern science the universal control over scientific knowledge, establishing a distinction between the true and the false. However, the coloniality of power over scientific knowledge goes beyond epistemological contradictions about the acknowledgement of the multiple scientific knowledges that permeate the different scientific productions. The colonial relation of the scientific production promotion is part of the agreements of a global capitalist agenda, in which hegemonic countries reinforce their centrality from practices in which the hierarchical nature of North-South relations still present through capitalist and imperial relationships, e.g., the space (Larivière et al., 2015), which is intended to publish productions from the Global South in scientific journals that have been gradually recognized as entities that legitimate the quality of scientific articles, provided they reproduce models established by schools from central countries. the lack of space reserved for evaluators from

\footnotetext{
${ }^{2}$ For the sociologist, these norms would be based on four principles: 1) communalism (scientific knowledge is a common good of humanity); 2) Universalism (scientific papers must follow universal standards of evaluation; 3) disinterestedness (Separate Science from personal interests); and 4) organized skepticism (the scientist must be deprived of any form of prejudice and hasty conclusions on its works).
} 
periphery and semi-periphery countries, as members of scientific committees in these same journals (Dhanani \& Jones, 2017); the imposed reproduction of methodological models and the infrastructural dependence on measurement and evaluation systems of science (Haustein, 2016). These are some of the examples of Northern dominance over the South, through the naturalized and unnoticed epistemic colonization in which the spatial and temporal issues are fundamental to this discussion. Or rather, the lack of space and entangled temporalities make the science from the Global South tangential, as an expanded place (Resende \& Thies, 2017) acknowledged and assumed as fundamental to understand that specific, established and fixed models attributed by the political and economic dominant order are intertwined with postcolonial models and challenge the world (dis)order (Levander \& Mignolo, 2011). In this sense, rather than a negation of dominant models, this constitutive view on epistemologies of the South invites us to reformulate the former colony countries paradigms from perspectives that expose the power conflicts and the ideological naturalization of subordination, exclusion and peripheral status (Mata, 2014). Epistemologies of the South, in their postcolonial perspectives, should be perceived as the meeting of different concepts on knowledge and power (Santos, 2008).

According to Luciana Ballestrin (2013, p. 94), "the change in the redefinition of the political and cultural spheres in Latin America during recent years has led several intellectuals in the Continent to revise previously established epistemologies in the social sciences and humanities", acknowledging the need for development of epistemological currents originating from the places where they live in, looking for categories that are fundamental to the region (Castro-Gómez \& Mendieta, 1998), since the Latin American continent occupies a central place, proper to perform the coloniality, since it was the first periphery of the world-systems theory and it was also the first opportunity for primitive capital accumulation (Castro-Gómez, 2005).

According to Cicilia Peruzzo (2016), the participatory research - specially the action research - can be put in the debate and in the proposals of decolonization of science, in the proposal of a epistemology of the South, by proposing alternatives to the knowledge production coming from Eurocentric models and recognizing the existence of multiple knowledges, thus favoring the formation of individuals capable of critical thinking outside university institutions (Maldonado-Torres, 2008). Thus, in Latin America, action research emerges as one of the ways to understand this multiple ecology of knowledge by bringing research subjects as active and acting agents of knowledge production that are not necessarily within in the restricted space of scientific knowledge production. Action research recognizes the research agents as subjects (collective or individual), besides "the potential of building scientific knowledge regarding the use of research agents as active participants, co-protagonists - and not mere informants/subjects - using these agents in the elaboration of plans, interpretations and the empowerment of results" (Peruzzo, 2016, p. 66), thus enabling the recognition of other knowledge within the ecology of knowledge beyond the knowledge imposed by the hegemonic scientific rationality.

Since the 2000s, action research has been growing in Brazil, as pointed out by Etienne Lima and Fábio Silva (2017). Based on the understanding that action research 
comes, in this scenario, of a typical epistemology of the South (Peruzzo, 2016), we want to investigate how this type of research has been developed in Brazil, trying to answer if this type of research is one of the forms of knowledge originating from this post-abyssal thought. So, we want to understand how the action research has been presented in Brazilian scientific productions? What is the action research profile in Brazil? These are the questions that lead to this work. We therefore want to investigate what types of action research practices are being developed in the Global South, trying to weave, using cartographic methods, the consolidation of a research network on the theme. To do so, as an initial clue to this research, we will scrutinize Brazil, where this type of research began in Latin America, using research practices of Paulo Freire in the 1970s (Gajardo, 1985) in the field of education, whose academic interest in Brazil has increased more and more since the $21^{\text {st }}$ century (Lima \& Silva, 2017).

\section{IN SEARCH OF AN INVISIBLE SCIENCE AND ITS APPROACHES USING THE EPISTEMOLOGY OF THE SOUTH}

In order to understand the scientific environment, first, it is necessary to recognize the multiple agents that make up the relational schemes of science. Among the actors involved in the contemporary scientific movement are the major publishers, responsible for indexing scientific journals and for legitimizing and validating the quality of the periodicals registered in their database, limiting the promotion of scientific articles only to a group of companies that control the scenario, forming a "scientific oligopoly" (Larivière et al., 2015) composed by a group of six major companies: ACS, Reed-Elsevier, Springer, Wiley-Blackwell, Taylor \& Francis, and Sage. The consolidation of this scientific publishing industry has been subject of much debate inside and outside the scientific community, especially in relation to the high margins of profit of these main publishers, their lackluster criteria used to evaluate papers and the publication of researchers' articles, mostly European and North American, silencing and making the knowledge developed in other countries invisible, especially in areas considered less strategic to the global agenda (Wagner \& Wong, 2011).

In this scenario, we can observe an organization based on the geopolitics of knowledge (Mignolo, 2008), in which capitalism and globalization coordinate the attitude, positions and power conflicts in this global scientific environment, in which the publishing companies dominate the scientific market of knowledge and dictate standards for impact and quality evaluation and scientific legitimacy. In this capitalist-ruled scenario, two scientific production groups are established in a way that creates an abyssal gap between what is hegemonic and what is peripheral, that is, what is on the other side of the line, made invisible in these spaces "recognized" by science through power conflicts. That is, "quality science" and peripheral science are created, a science that is not measurable by the models of scientific evaluation, a practically "invisible" science. It remains for us to ask: invisible to whom?

Such a question meets Boaventura de Sousa Santos writings who argues that modern Western thinking is abysmal. According to the researcher (Santos, 2007, p. 11), there 
is a system of distinctions based on a system of visibilities and invisibilities, whose distinctions are "established through radical lines dividing social reality into two distinct universes: the "on this side of the line" and the "on the other side of the line". According to him, the division is built in such a way that what is considered "on the other side of the line" disappears as a reality, rendering non-existent what is produced in this other scientific production circuit. This abyss "consists in granting to modern science the monopoly of the universal distinction between the true and the false to the detriment of (...) alternative knowledge entities" (Santos, 2007, p. 47). According to the Portuguese scholar, it is necessary to democratize and decolonize knowledge, recognizing the importance of multiple epistemologies. Therefore, it is necessary to admit that knowledge is a tool that must be served beyond the traditional spaces of knowledge production, starting from the notion of open access, sharing and public commitment, crucial elements of Latin American science (Vessuri, Guédon \& Cetto, 2014).

Still, knowledge can be represented in multiple forms, "including text, image, numbers, history, music, drama, poetry, ceremony, and meditation" (Hall \& Tandon, 2017, p. 13). Therefore, it is important to point out that the geopolitics of knowledge, whose colonialist view remains to be reproduced, needs to be relativized, considering cultural contexts and resistance and liberation practices through scientific research itself.

But for this, it is necessary to understand the knowledge production from a decolonial perspective, which "implies thinking from languages and categories of thought not included in the foundations of Western thought" (Mignolo, 2008, p. 305). For Santiago Castro-Gómez (2005, p. 80), decolonizing the Latin American university means introducing postcolonial thought through the incorporation of transdisciplinary and complex thinking that allows a cognitive exchange between Western science and other "postcolonial" knowledge production. Rather than seeking to overcome the colonial thinking implied by the prefix "post", the decolonization of the university is not a "reversion of the colonial moment by the postcolonial" (Colaço, 2012) but rather an attitude of continuous struggle for a more open, plural and participative university.

Therefore, it is not only the denial of a hegemonic scientific research ${ }^{3}$, but the understanding that these contributions are not enough when one understands scientific production goes far beyond the paradigms and models of traditional scientific scenario. To understand what has been produced in knowledge terms, it is necessary, therefore, to recognize the knowledge production spaces in territories that are not part of a hegemonic axis of science, a challenge that this research seeks to supersede. To decolonize science means - at the same time - to unveil the colonial thinking and reproduction of the colonial matrix of power, for example, by discussing linguistic and cultural issues and the own structural barriers of scientometrics while disconnecting from the totalitarian effects of subjectivities and categories of Western thought, seeking to weave methods that consider the scientific knowledge production in its broader understanding. In this sense, Santiago Castro-Gómez (2007) proposes other paradigms based on transdisciplinarity

3 Here, the spaces of traditional scientific publication are understood and defined, e.g., close access web portals of publishers and indexing libraries that corroborate for a hegemony of the knowledge under commercial principles. 
and complex thinking as emerging models of the transcultural dialogue of knowledge between Western science and post-Western forms of knowledge production.

In this sense, the notion of a post-abyssal thought emerges (Santos, 2007, p. 85) "as a learning from the South using the epistemology of the South. It confronts the monoculture of modern science with an ecology of knowledge, which is based on the recognition of the plurality of heterogeneous knowledge". This thought seeks to recognize the inexhaustible diversity of heterogeneous knowledge production, beyond that which is legitimized by scientific rationalism, proposing ways of constructing an epistemology comprehending these multiple knowledges (only one of them being modern science, as we know it). That is, it is not a denial of modern science, but a recognition that it is not capable of explaining the entire reality and that it can create an abyss between what is legitimized by its own epistemologies and validated by scientific rationalism, in a distinction between what is "scientifically truth" and what is common knowledge. We are faced with different levels of abyssal circuits in the scientific environment: on the one hand, a separation based on the geopolitics of knowledge from academic publishing circuits consolidated around capitalist practices of a hegemonic scientific publishing market, which distinguishes the hegemonic science and periphery science production circuits; and on the other, in local subgroups, the distinction between what is scientific, and what is based on methodologies validated by the hegemonic science agents is enforced, and what is on the "other side", the knowledge that is popular, the other group of knowledges.

In face of this social organization of science, and in face of action research, which seeks to overcome such contrasts, and to develop an epistemology directed to the Global South of its own, proposing another way of relating to the abyss between the hegemonic science and the periphery of global science, a step that recognizes the ecology of multiple knowledges, joining scientific knowledge and popular knowledge, in this scenario of post-abyssal thinking, respecting the forms of thought and needs of the peoples in the Latin America. As Cicilia Peruzzo (2016, pp. 6-7) points out, "a new way of seeing and conceiving science, and of producing scientific knowledge, is under development in Latin America - and not only in Latin America - since, at least, for the last four decades of the last century". Cicilia believes that action research has improved, seeking to position this type of research within the scope of scientific epistemology, breaking away from certain dogmas and weaving methods to qualify the inclusion of the researcher beyond political spectrum. Action research "gives credibility to the development of powers of reflective durations, discussions, decisions, and actions of ordinary people who participate in a collective research on "private problems" that they have in common (Adelman, 1993, p. 9).

As we know, no science is neutral in its political aspects, but it follows the objective interests of social classes shrouded by a hegemony in development, accumulation and dissemination of knowledge (Fals Borda, 2012). Action research comes from a "search for new assumptions in the production of scientific knowledge that relativizes the assumption that the only valid knowledge is the scientific, and that it can only be obtained if it is developed according to the canons of empiricism, objectivity and of the alleged neutrality, principles which are constructed and reproduced from Western scientific culture 
of a positivist nature "(Peruzzo, 2016, p. 5) Action research, therefore, concerns the development of an epistemology in which the researcher is not only an active subject in research but has a balance of powers between the other agents involved in the research experience, an epistemological nature of the Global South.

\section{EPISTEMOLOGICAL ASSUMPTIONS OF ACTION RESEARCH}

In the face of this scenario of scientific conflicts and oligopolies ruled by capitalism and globalization (Mignolo, 2008, 2013), alternatives to Latin American social thought are conceived in the opposite direction to the colonial organization of the world. A coloniality expressed by neoliberal thinking that, according to Lander (2005, p. 14), has a hegemonic force that nourishes a notion of objective and universal character of knowledge, which is articulated "by the segregation that dictates what is social knowledge between modern society and the other cultures". Thus, a range of alternatives to modern knowledge is linked to the Latin American context in questioning the colonial character of social knowledge. The author points out that a new way of conceiving the world towards the abolition of this segregationist system that marginalizes the Latin America. It is the understanding of a paradigm that articulates the idea of community, of liberation through praxis, of redefining the social researcher's role, of historical character, of epistemic plurality, of resistance, and of revising methods and transformations made by it (Lander, 2005, p. 15).

In this sense, several contributions are identified aiming to compose the Latin American social thought paradigm in the geopolitics of knowledge context. Action research is one of these propositions with the objective of seeking a convergence between popular thought and scientific knowledge and overcome the distinction between subject and object, a characteristic of positivism, and for being inspired by a pluralistic democratic concept (Fals Borda, 2012). Thus, action research can be applied in several fields of knowledge and for different purposes, action research, which positions itself in the scientific context as a methodological proposition made to reinvent traditional methodologies, it presents us how a researcher acts and behaves within the investigative process, this is a fundamental aspect in the elaboration of a research. Thus, there is an intimate relationship between the subjects considered and the action proposed, accompanied by a social transformation that is revealed as a central aspect of this methodology (Thiollent, 2009).

Action research was developed in the post-World War II era, becoming popular in Latin America in the mid-196os. Its theoretical and epistemological base comes from Germany, an idea of the psychologist Kurt Lewin, who believed that action research is an important psychological intervention strategy. He was a Jew and outraged by Nazi oppression, Kurt positioned himself as a champion of social change, proposing a methodology in his academic studies that would be useful to society, with social justice and rigorous research: action research (Melo et al., 2016). However, despite the term coined by Lewin, there are disagreements over the person who developed the process (Tripp, 2005). Sometimes, in the scientific literature, action research is considered a type of 
thought on action, disregarding action research as a form of investigative process that requires action both in the practical area and in research.

According to Barbier (1985), action research reveals itself in the post-war context to address issues relevant to the social conjuncture of that time, as well as happened in the United States after the First World War, they investigated social problems in urban areas. It is in this context that action research thinks about the man's role in society and proposes a transformation of objects into social subjects, making the production of knowledge something collective and identifying a social genesis that precedes theoretical genesis. The purpose is to serve as an instrument of social change (Barbier, 2007), without separating the knowledge production from the practice performed to achieve such change.

Thus, the action research methodology presents itself before a gap between theory and practice. Although the action-research term is widely used, Peruzzo explains that sometimes other names are used as "participatory action research, or simply participatory research, active research, study-research, investigative action or militant research, according to the vision of each author and the theoretical traditions that underlie these names" (2016, p. 2). Peruzzo discusses these conceptual discrepancies and the use of all these terms. The author uses the participant research to understand the specificities of action research, which can be considered a participant research modality (as well as participant observation method), which has as basic objective including the researcher in the environment of the phenomenon and/or group being studied, and the researchergroup or phenomenon interaction. However, in the specific case of action research, Peruzzo adds that "the researcher not only shares the studied environment, but also allows the investigated to participate in the research process and that the results can become a benefit for the studied group itself" (2003, p. 3). On the other hand, despite the current directions of participant research, which is still a constant search for scientific legitimacy, we need to consider the complexity of this methodological field, which comes from many debates about including the researcher into the researched environment and this way of conceiving and doing research in Human Sciences, even participatory research being applied in several areas of knowledge, such as education, sociology, communication, anthropology, administration, engineering, among others,

It is not a question of abandoning a model of scientific domination used as a form of acting in research, but a way of transforming, or even transfiguring, the hegemonic models in the redefinition of scientific plans. Fals Borda (1981) praises what is supposed to be the true role of the current active scientist, which should be to check relevant questions prior to the research results such as: "what kind of knowledge do we want and need?"; "What is scientific knowledge intended for and who will benefit from it?" (p. 47). However, the same author adds that the intention is not to form a new scientific paradigm through participant research, replacing an existing one, but rather to question the need for a centrality in the process of producing scientific knowledge, much more than in the final product.

However, we can approach some sort of methodological gap if the involved researchers follow the dynamic effects of the breakdown of the subject-object 
dyad that this methodology demands as one of its basic characteristics. The potentialities of obtaining a new solid knowledge from the establishment, in research, of a more fruitful subject-object relationship, that is, a complete integration and participation of those who undergo the research experience. (Fals Borda, 1981, p. 59)

Therefore, we propose an innovative epistemological and methodological discussion on the appreciation of scientific doing, presenting action research as a method that dialogues with innovation and empiricism. Action research is a liberating and emancipatory method to break away from "the imposed habits, customs and bureaucratic systematization" (Barbier, 2007, p. 59). We want to distance ourselves from a discourse focused on the universality of science and the neutrality of scientific production. "Science is historical, it moves, advances, and becomes something in conformity with the very historical process of civilizations. Therefore, if science is not univocal, so the epistemology of science is not", which means that participatory research is based on a departure from positivism and in the approach to the Dionysian view (Peruzzo, 2016, p. 4). This notion of epistemology, according to Peruzzo, helps in understanding the controversies that follow scientific knowledge and its validation, corroborating to a notion with an even greater dimension, the notion that the epistemology of the South has in the participant research the "entrance doors to the construction of knowledge", given the context and Latin American scientific logical thinking.

Therefore, this seems to be a good moment to be more emphatic and briefly introduce the general assumptions on action research, due to its clear proposal of rupture with the canons of empiricism and models created and sustained by Western scientific culture from a model of thought and action spirals. For this brief discussion, we use a basis the general aspects of the action research pointed out by Peruzzo $(2016$, p. 9), which highlights the "participation/inclusion of the researcher, type of action, researcher's participation and the return of the results".

\section{PARTICIPATION/INCLUSION OF THE RESEARCHER}

Carry out an action research requires a continuous and effective participation of the researcher within the scenario and the reality in which the phenomena and/or group studied occur. Barbier (1985) action research is positioned as a current that not only drifts away from positivism but proposes an event or everyday life sociology. Thus, the researcher's participation is focused on monitoring the dynamics of the everyday life, so the researcher also has the autonomy to act. For this interaction to take place, prior authorization from the group or community is required.

In the inclusion phase, the researcher becomes closer to the group, this occurs when the researcher assumes its role as research coordinator. This function must be separated from the relation "oppressor and oppressed" or "master-apprentice", an issue pointed out by Paulo Freire (2005). Applying action research is to move away from the "banking model of education", where educating becomes the act of depositing knowledge, which 
disregards consciousness and the dialectical process, but rather approaches research in the liberating perspective. The researcher is not a "trainer" of the studied group, but a "mediator", although autonomous and owner of its practice and speech, who has the purpose of developing an active role in solving the problems encountered, follow-up and evaluation.

\section{TYPE OF ACTION}

The action in the action research is twofold: the researcher's action and studied group's action. Peruzzo (2016) explains that this action differs from the conventional one in the ethnographic research concept, participant observation and traditional anthropological and psychological currents. In the action research, the researcher not only observes, but also acts freely, focused in the cooperation and collectively with the subjects from the studied group. In the definition of Thiollent (2009, p.16), action research is conceived and carried out in "strict association with an action or with the resolution of a collective problem, in which researchers and participants representing the situation or problem are involved in a cooperative or participative manner".

\section{RESEARCHER PARTICIPATION}

The researcher has an active role in action research, which is not to separate the researcher from thought and action, from facts and values. Involvement between the researcher and the subjects of the research results in several levels of involvement. Thus, the participation of people that are subjects of the research is not considered a mere collaborative action but in actions that originate from the strategic elaboration of an actions plan to the effective performance of the research and debate on the data obtained with the results. It is a participation based not only on the researcher interests but on an effective and continuous contribution to the studied subjects, from the development of a collective knowledge and, thus, proposing a decolonization of knowledge.

Action research intends to overcome the of traditional scientific knowledge thinking by incorporating a social-political function, which is in line with the researcher's participation in the effectiveness of action research. Thiollent (2009) associates this political function with an action or resolution of a problem that must have as basic principle the collective and cooperation, where the studied subjects have something to say or do. Research and the way the researcher and research subjects conduct the research is directly linked to the proposed transformation policy. However, it is also necessary to consider the limitations existing in this process and to acknowledge the structural aspects of the social reality researched. Actions can only be structured and transformative if the subjects involved are aware of all these issues. Moreover, these changes are necessarily limited, since the social system is not definitively altered, and the transformations evoked here by action research occur directly in people's consciousness. 
Fair appreciation of the scope of changes associated with action research does not go through unique criteria. Each situation is different from the others. When the actions acquire an objective dimension of easy identification (for example: production, collective manifestation, etc.), the results can be evaluated in tangible terms: quantity produced, number of people mobilized, etc. Action is coupled to several subjective factors, and therefore it is necessary to distinguish several degrees in the awareness. (Thiollent, 2009, p. 47)

\section{RETURN OF THE RESULTS}

Return of knowledge is one of the great differentials of action research, drifting away from the normative assumption of conceiving science traditionally and of the "laboratory" concept, not following all these scientific standards. The return of the search result is often expected by the studied groups, but rarely benefits them. In action research, this beneficial return occurs throughout the research process and in a final step with clear and accessible language for everyone's understanding. Peruzzo (2016, p. 13) explains that action research assumes a democratic distribution of these results throughout the research because "the own steps outlined will enable participation in the discussion on "findings" because there are forums and seminars for presentation and discussion of partial results and internal research organization".

On the democratic distribution of this knowledge and the return of the research results, Fals Borda (1981) adds that it must be systematized, organized without intellectual arrogance, he proposes some rules for the "systematic restitution". The first rule deals with differentiated communication, which must be adapted according to the level of political and educational development of the studied group. The second determines the need of a simple communication method, prioritizing a language accessible to all. Next, the author suggests a self-research and control, in other words, a control of the research process by the studied group. This rule draws attention to the controlled autonomy of the researcher, who cannot decide alone what should be researched, but rather decide along with the subjects in the research group, starting from dialogical relations and interrupting the object-subject relation within the research. Finally, the last rule assumes that a scientific popularization, acknowledging the research techniques and presenting them in a way accessible to the groups.

\section{Cartographies of action research in the Global South}

New ways of perceiving and conceiving scientific knowledge are constantly being built in Latin America, that is, alternative ways to Eurocentric-colonial thinking. Latin America undergoes a change of perspective when putting itself "in Our position" (Lander, 2005). An epistemology of the South has been formed, becoming evident the urgency of an epistemological thinking. According to Santos (2007, p. 20), it has never 
been so clear "that the understanding of the world is much broader than the Western understanding of the world", which explains the globalization context and the weakness of social theories. The big problem for those living in the South is that Western theories do not fit the realities of countries that are not part of the hegemonic axis.

The difference between theory and social practice reveals the birth of a Southern epistemology - the decolonization of science - and raise the need for a new mode of knowledge production (Santos, 2007). In this context, participatory methodological propositions gain strength as an alternative to new ways of conceiving thought, with action research being one of these possibilities, by going beyond the limits of action and strengthening awareness through participatory and thoughtful empowerment. In addition to generating concrete answers to the research group problems, action research allows the expansion of knowledge-building processes, establishing itself with a "new perspective on society, knowledge and science" (Colmenares, 2012).

Based on this scenario and trying to understand this process of knowledge construction based on participatory methodologies in the Global South, we have carried out a collection of scientific publications in Latin America on action research published in the last 17 years (2000-2017), since studies indicate a growth of researches on the topic since the 2000 s (Lima \& Silva, 2017). We intended to investigate what types of action research practices are being developed in the Global South, trying to trace, using cartographic methods, the consolidation of a research network on the subject.

Due to our understanding of such lack of space for publishing Brazilian and Latin American articles in scientific oligopoly journals, our collection sought to use other ways of measuring the promotion of scientific production on the subject, since traditional bibliometric searches using the Web of Science or Scopus' Science Direct do not make the scientific panorama from periphery countries visible (Wagner \& Wong, 2012). Thus, this research sought to use other sources, such as Google Scholar, that allows a broader measurement of Brazilian research (Mugnaini, Strehl, 2008), although the scientific rigor for indexing is not very relevant. To do so, we used the Publish or Perish software to extract the data, searching for the papers "investigación acción" (951) and "pesquisa-ação" (856), totaling 1.807 categorized papers. Through the software, from each publication, we obtained the number of citations, author, paper, year, source, publisher, article URL, citation URL, among other data. To carry out a more in-depth investigation, we will analyze the data on action research, which comprehends the Brazilian scientific reality.

Of the total number of entries identified $(n=856)$, only two papers were indexed by the large commercial publishers that are part of the scientific oligopoly, representing $0,35 \%$ of the total papers found in this sample, reinforcing the existence of a science invisible in the scientific market. The two sample papers present in the scientific oligopoly circuit are indexed in Elsevier. The indexing bases that appear with greater emphasis in the other papers analyzed are Redalyc, SciELO Brazil and Bireme, which are relevant bases in the context of Latin America (Babini, 2011). Action Research Journal, for example, is a journal owned by one of these great publishers who command this scientific oligopoly, Sage, and there are only two publications by Latin American authors in the last three years 
in published editions. In the editorial committee there is only one member from Latin America, who is from Mexico, despite having several members from the Global South. Despite the interest in the subject, and a tradition of the use of action research in some fields of knowledge such as education, for example, which has been highlighted since the works of Paulo Freire and Fals Borda in the 1970s, Latin American researchers have little space in the journals of large commercial publishers like Sage, either in the publication or in the evaluation space and quality legitimation of the material to be published. This brief review considering the last three years of publication of the Action Research Journal 4 shows how Latin American science is often invisible and tangential in the areas of great scientific circulation, thus, it is necessary to develop other methodologies to measure science beyond the platforms widely used as Web of Science and Scopus.

The collection was based on two searches using the keywords: research-action, for collection of publications by Brazilian researchers and investigación-acción, for the publications by Latin American researchers, excluding publications of researchers from Spain and other Spanish-speaking countries. This procedure aimed to quantitatively understand how the discussion on action research has evolved in Latin American countries, including Brazil, seeking later to delve into the publication profiles only in Brazilian productions.

In terms of its characteristics, the first graph (Graph 1) presents an overview of action research (Brazil) and investigación acción (Latin American countries) from 2000 to 2017, and it is possible to observe a stability of research-action in Brazil in the last five years and a decline in Investigación Accion in the rest of Latin America in the same period. Although the research is focused in these two terms, from the conceptual point of view, the nomenclatures vary according to the theoretical traditions. Peruzzo (2016) explains that action research is an Anglo-Saxon (action-research) and French (recherche-action) expression, particularly, from the Kurt Lewin research, with America Latin America influenced by the term participant research. In the Brazilian context, Paulo Freire, Carlos Rodrigues Brandão and João Bosco Pinto must be emphasized, with the participant research expression in a first moment. In a second moment, the research-action denomination is predominant with Michel Thiollent and Fals Borda adopting such nomenclature, among others.

From this analysis, we can perceive the increasing interest on action research in Brazil, justifying our clipping about research from what has been published on the subject in the country. We do not mean that this is a type of research is common in Brazil, because the countries' scientific production is diverse and respond to the local agendas in each field of knowledge. As well as it is not possible to affirm that action research is a phenomenon endemic to Brazil, because as pointed out previously, many researches using this method have come from researchers of different nationalities, as in the Action Research Journal, for example. However, the increasing numbers of this type of research shows us a recurring interest in the country, in different areas of knowledge.

${ }_{4}$ Avalibale at http://journals.sagepub.com/home/arja 


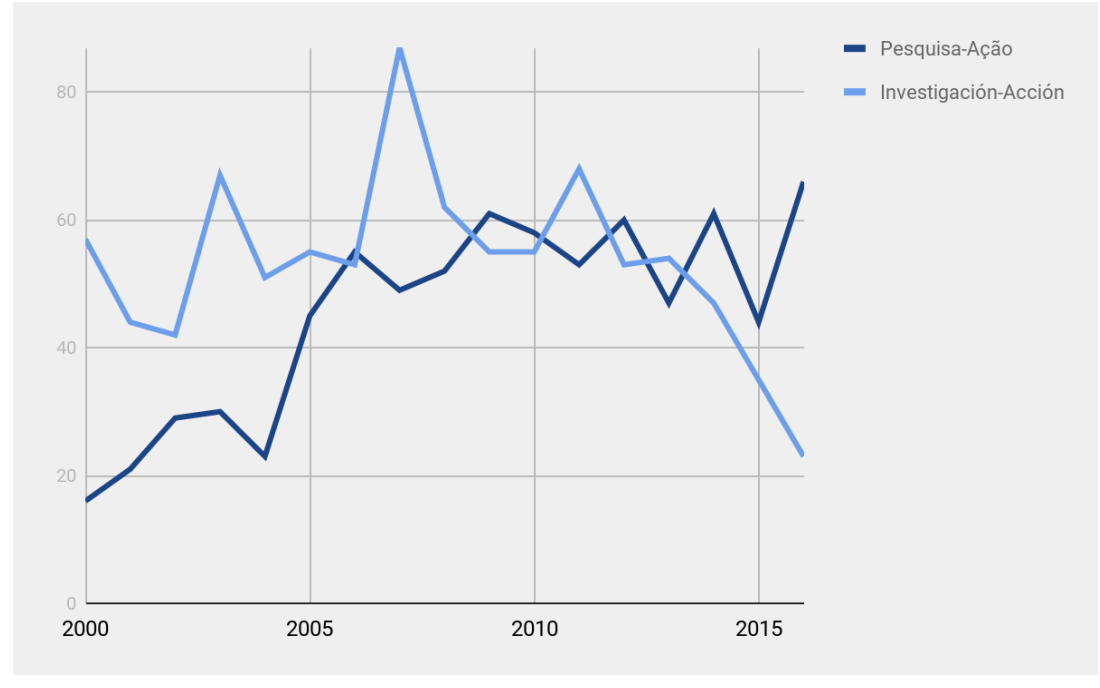

Graph 1: Action research and investigación acción development

Despite the different expressions to name action research in the most different contexts, there is no single and specific value to define it. The multidisciplinarity and the most varied appropriations of this research practice are characteristics that define the essentiality of action research, which can serve different interests depending on its purpose and epistemological current. From this interdisciplinary character, we can observe, in fact and within the Brazilian scientific reality, the appropriations of the research process practices proposed by action research in different areas of knowledge (Graph 2). For this categorization, we took as a basis the division of fields of knowledge defined by the Brazilian National Council of Scientific and Technological Development (CNPq), thus dividing the papers into eight major fields: Agrarian, Languages and Arts (LLA), Health, Applied Social Sciences, Mathematical and Earth Sciences, Humanities and Engineering.

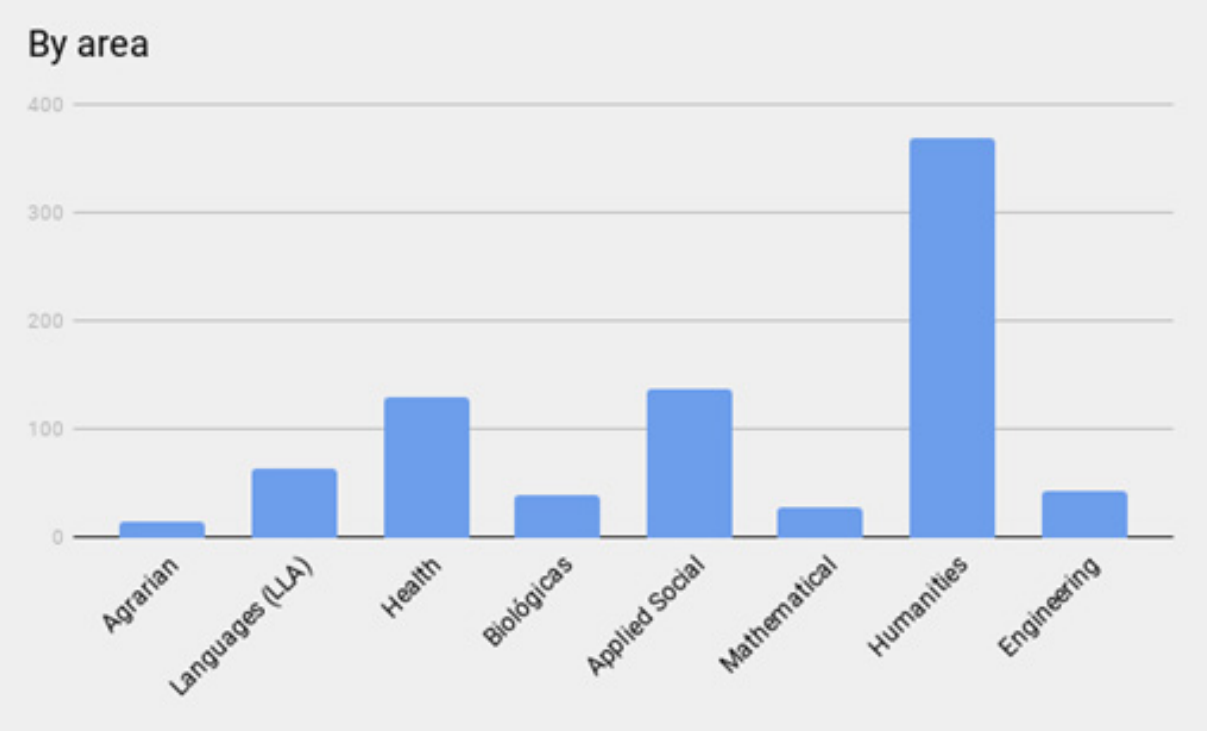

Graph 2: Action research by field of knowledge 
The categories of knowledge areas were raised to divide the material extracted, but it is important to note that sometimes they interconnect, which is due to the existence of multidisciplinary titles ${ }^{5}$. Thus, we observed that some productions could be classified in more than one category and, therefore, we take into account expressions and keywords contained in the titles of the publications for the accomplishment of an individualized categorization in all the listed files.

As we can see in the graph above, the productions related to action research in the field of Humanities stand out from the other fields, accounting for 368 papers. Most of the productions in this category fall under the theme of Education, reflecting a trend coming from the early studies on action research in Brazil, mainly proposed by Paulo Freire, due to its frequent use in the application and understanding of educational pedagogical practices, even though it assumes a multidisciplinary character. According to Barbier (2007, p. 19), who is an important researcher of action research and its approach to educational institutions, this relation reflects the pedagogical and political characteristics of action research, serving as a basis for the formation of a citizen concerned with the city's collective organization. Thus, it is part of the formation category par excellence.

According to the categorization process by field of knowledge, we have the category Applied Social Sciences (137 papers), Medicine (129 papers), with few papers separating one from another. The approach is a response to the attempts of consolidating action research in different fields of application, resulting in a multidisciplinary performance with different theoretical-methodological aspects. For example, Tripp (2005) is a strong supporter of the use of action research by researchers in the Humanities and Social Sciences. In medicine, Sommer (1999) and Williamson and Prosser (2002) emphasize the use of this methodological contribution to practical changes and generation of new knowledge from the empowerment of the participants in medical research, although they raise some reservations, such as ethical aspects (Melo et al., 2016). Thiollent (2009) points out some of the fields in which action research can be applied such as: education, communication, social service, rural development, political practices, and draws the attention to the use in more technical fields such as production engineering, agronomy, architecture, among others.

Only Medicine, Humanities and Applied Social areas have publications in all analyzed years. With regard to the themes of these papers, there is a predominance of theoretical-methodological discussions in almost all fields of knowledge, being this also the papers with the largest number of citations, which correspond to books and chapters, not counted by the large companies that dominate the "scientific oligopoly" (Larivière et al., 2015), which disfavor the measurement of the scientific impact of productions in action research, rendering invisible the production of knowledge from an epistemology that unites scientific and popular knowledge. This scientific scenario also represents a role that has been played by the South in the construction of scientific knowledge with strong influences of the Western scientific thinking, making it necessary to reinvent social

${ }_{5}^{5}$ We therefore acknowledge how limited this research can be in the proposed method for defining categories, which sought to consider the particularities and common multidisciplinarity in action research. 
emancipation from the South through an organization outside the hegemonic centers (Santos, 2007).

University-Society relationship is another trait observed in the action research profile within the Brazilian reality. The term university comes from the Middle Ages to name any entity that aggregates a set of individuals with the same purpose, without necessarily possessing the institutional character of modern universities. Second Leonor Paini, it was enough that the students were linked to a master and follow their teachings so that this aggregation was called schola or "family". "Universities" in their broad sense at the time could happen anywhere, and "knowledge was considered a divine 'Gift' and as such, it would belong to any Christian who was bestowed by God and thus had the gift of knowledge of Latin language" (Paini \& Costa, 2016, p. 60). Nevertheless, according to Leonor Paini, there was already a monetization of knowledge, since the university students paid the classes taught by the masters.

According to Chauí (2003), the modern university becomes what is known to us today after the French revolution and in the nineteenth century, its main aspects, such as teaching, and research are constituted. In Brazil, the first specialized schools were created together when the Portuguese monarchical seat was transferred to Brazil, without, however, being considered as a university. Until the Proclamation of the Republic, the model of higher education was based on the training of liberal professionals and "the objective was to grant a professional diploma in order to ensure a certain social prestige and the occupation of privileged posts in a restricted labor market" (Paini \& Costa, 2016), which was reinforced with the country's modernization project, which took place in the decades of 1920/1930. At that time, as in the extension models from other countries that came from political and economic crises, the university came to include a third function, in addition to those already consolidated, which are teaching and research: the extension, which in the 1980s was understood in Brazil as an educational, cultural and scientific process that articulates Teaching and Research in an inseparable way and enables the transformative relationship between University and Society (Forproex, 2002). Through extension, the university "has a role of transferring knowledge and mobilize the community, so that the theoretical knowledge acquired in the university, added to the possibility of practical experience, could produce changes in response to market failures" (Bachmann \& Parisotto, 2016, p. 22). However, it is precisely in this period of re-democratization of the country that this third mission of the university by its extension begins to acquire new shapes, mainly due to a closer partnership between the public university and the private companies, aiming at financing researches that meet their needs and mutual interests. In this sense, the market has emerged as an important factor in the consolidation of the university ethos, mainly due to changes in the public policies that opened the incentive to innovation in the country. Such conflicts over the control of this third function of the university meet what Boaventura de Sousa Santos points out as knowledge-emancipation and knowledge-regulation. According to him,

it is an understanding and intimate knowledge that does not separate us and rather unites us personally to the object of our studies. It is not a matter 
of medieval amazement in the face of a hostile reality possessed by the breath of divinity, but rather of prudence in the face of a world which, though domesticated, shows us every day the precariousness of our life's meaning, however secure it may be in survival aspect, and for the overwhelming majority of the world population is not. (Santos, 2000, p. 84)

According to the author, the modernity project is based on two forms of knowledge: knowledge-as-emancipation and knowledge-as-regulation. Knowledge-as- regulation pillar is composed by the state, the market and the community/society, whereas in emancipation-as-knowledge it is possible to identify three forms of rationality: the aestheticexpressive, the cognitive-instrumental, and finally the practical-moral rationality of law. In contemporaneity, we observe knowledge-as-emancipation being absorbed by regulation, from the convergence between modernity and capitalism and its rationalization based on modern science. Boaventura de Sousa Santos believes that this overlapping of knowledge-as-regulation on knowledge-as-emancipation occurred through the imposition of scientific rationality and market regulation on the state and community, thus making hegemonic scientific rationality and market the only principle and modern regulator that crosses all spheres of society. Meeting what Moisés Martins (2015, p. 407) points out as a context of commercialization and datafication has also affected how people think in the university: "they [the universities] are subject to the same kinetics that drives the world, the technological mobilization to the market, that is, to answer to the demands of a civilization based on numbers". To the author, this movement of transforming knowledge into a potential commodity to meet the market demands has weakened the research itself, which in the name of accountability its "economic value" has been even more considered than its "scientific value" into the evaluation of science as a commodity, which is traditionally measured through the number of citations.

To stop this imposed regulation and to emancipate knowledge, new paradigmatic models are needed in which it is possible to transform scientific knowledge (totalizing and undemocratic) into a new common sense, defined by Boaventura, as "prudent knowledge for a decent life". This understanding is in line with what Jésus Martin-Barbero (2014) reports on the existence of cognitive gaps that reveal the complicity maintained for more than two centuries between the rational monotheism of scientism and mercantilism that makes it profitable. To the author, convergence began to erode power over knowledge, established by scientific rationalism, in which researchers remain "entrenched in their authoritarian didacticism" (p. 5) maintaining little dialogue with the society. Although Barbero understands the convergence from a technological perspective, the dilution of the frontiers of the "traditionally modern" circuits of knowledge, surpass the technicality and converge to other senses: in the transdisciplinarity, in the multiplicity of social actors and in the recognition of the existence of diverse knowledge, by displacing the hierarchy of scientific knowledge.

In this sense, action research appears as a possible model of knowledge emancipation, integrating the community and science, the market and the state, as can be observed in the graph below. 


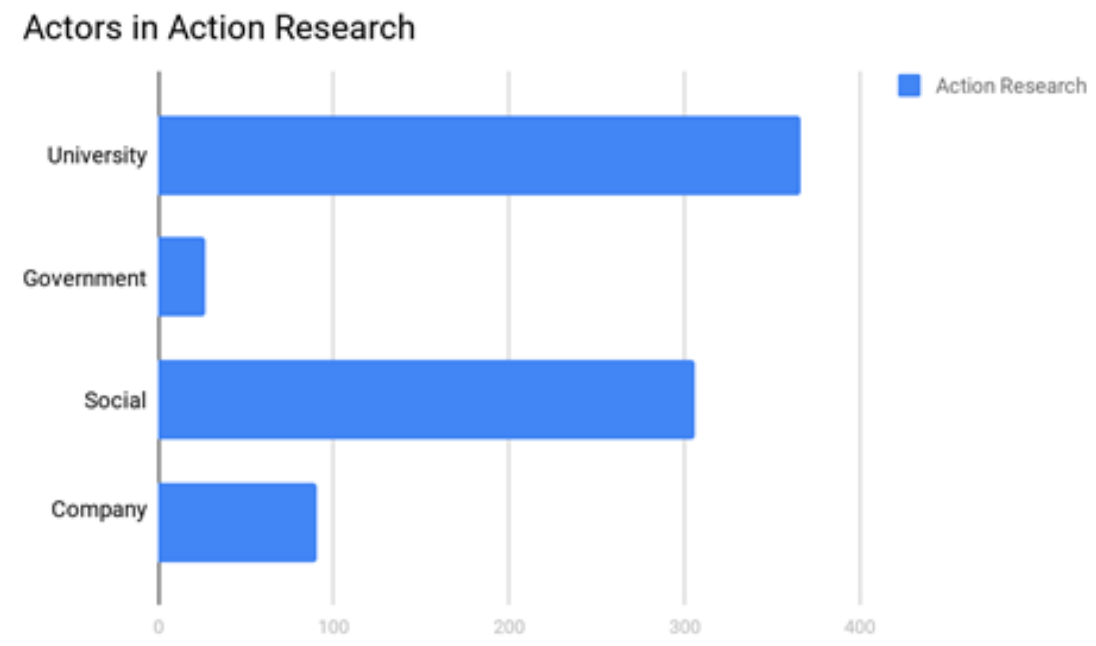

Graph 3: Participation of the four actors in action research

In this gathering of different possible actors to be described by action research, we observe a type of post-abyssal thought emerge, a type of emancipatory knowledge that seeks to integrate the multiplicity of the ecology of scientific and popular knowledge. This relationship is based on the Triple Helix model created in 1990 by Henry Etzkowitz and Leot Leydesdorff, which is a reference in the discussions about innovation processes, whose objective is to describe the innovation in the relationship between the University-Business-Government (Etzkowitz, 2003), considering multiple processes in the construction and dissemination of knowledge where "each Helix is an independent institutional sphere, but works in cooperation and interdependence with other spheres through knowledge flows" (Gomes \& Pereira, 2015, p. 138).

In this proposal, we consider, in the categorization of a sample of this research, the university, which has the role of providing in this system not only qualified subjects and research results, but prior to this, an intellectual capital that provides a distinct status in a knowledge-based society (Etzkowitz, 2003). Thus, all production with more theoretical and reflexive emphasis was placed in this category. The Government has the function of investing in public policies to strengthen relations in the triple helix model (Souza da Silva, Rocha \& Silva, 2013), being identified in the analysis in papers that are directed to the propositions that invest in public policies. "Companies should prioritize social responsibility and entrepreneurship through the management of innovation in services, products, techniques, etc." (Souza da Silva et al., 2013, p. 11). In this way, we note that company category permeates the production with a commercial nature, but these companies must deal with actions that promote social responsibility and entrepreneurship.

Although it focuses on a type of action that indicates three fundamental elements for the development of society, the Social category is not contemplated by the traditional Triple Helix model created by Etzkowitz and Leydesdorff. According to Lindberg, Danilda and Torstensson (2012) a fourth helix can be identified: society or the public sector, including media, creative industry, culture, values, lifestyle and art, which, according to 
them, also influence the innovation system and are not included in the traditional model. Thus, we consider in this analysis the fourth helix, the Society, identifying the papers where values and social demands were prioritized.

\section{FINAL CONSIDERATIONS}

Action research in Brazil has other features that goes beyond the bases of the scientific pillars established by the rules of the dominant science. We observed that there is a predominance of a University-Society relationship, reflected by a greater participation in the field of Humanities in the papers on research-action published in the studied period. The subject is in the centrality of the state of the art of action research as one of its basic characteristics, distancing itself from the subject-object dichotomy widely diffused by hegemonic and traditional science. Thus, the social nature of the scientific publications expresses a Global South attempt to break barriers held by Western science, inserting action research as a proposal of decolonization of science and an epistemology of the South (Santos, 2007).

However, although the social nature appears with a strong incidence in the papers collected in this systematic review, there is also a high amount of works with theoreticalmethodological directions towards the action research, being these most cited, which is a problem substantiated by the epistemology of the South, where "for a blind theory, social practice is invisible; for a blind practice, social theory is irrelevant" (Santos, 2007, p. 20). Thus, there is this trend to erase social practice from theory by the influence of Western scientific logic consolidated as an epistemology of the South. As a result, we perceive action research as something with little applicability in the practical social sphere, failing to fulfill the fundamental role of action research that is the transformation of the researched reality and subjects. However, this not means to deny the consolidation of action research in recent years in Brazil, in view of a notorious increase of the methodological proposal that is evident in the analysis of the material present in this research. We believe that the technical rationality of academic thinking has a great contribution in this process. In the context of the decolonization of science, we need a new way of producing knowledge (Santos, 2007) and action research is part of this debate as an alternative way of conceiving knowledge, but it is not immune to the academic thinking on production and scientific promotion. The scientific requirements multiply when we refer to action research, because there is a difficulty in reconciling scientific deadlines with the deadlines of an action research. The man's action time is not the same as that of the scholar man, revealing himself in scientific norms that match the perspectives of an academic "quality", which follows the "commercial ideology" logic in which "universities are corporations; education is a type of service; teaching and research are business opportunities; teachers are service professionals or consultants; the students are clients" (Martins, 2015, p. 409).

It is from a reality with social dynamics that action research can be carried out, proposing an epistemological radicalization and differentiating itself from other traditional researches. In this way, it plays a practical role that involves the resolution of a 
plethora of factors, evidencing its multidisciplinary character (Barbier, 1985). In this context, we were able to categorize papers in eight areas of knowledge defined by the CNPq, predominating Humanities and Applied Social Sciences, followed by Medical Sciences. The main topics addressed by medical sciences, regarding action research, are Nursing, Family Health and PE. The results obtained with the categorization by field reveal the metamorphosis of action research that runs not only in different fields of application of knowledge but also the "field of the epistemology of science that transits between innovative practices of empirical research, but far from empiricism, and the epistemological questions of the scientific doing itself" (Peruzzo, 2016, p. 3)

Looking to develop a map of action research in Brazil, we also observed that the level of production of studies on this subject have stabilized in the last five years, tending towards a possible progressive growth. Much has been debated about the strategies of insertion of the researcher in the researched environment, but little has been presented and deepened in theoretical-methodological discussions in the Brazilian context. We believe that this is an urgent need, aiming at a more rapid and effective promotion of the knowledge on action research for the formation of a stronger and decolonized scientific methodological network of traditional scientific practices.

This research aims to discuss action research as one of the possibilities for the development of an epistemology of the South, in which scientific knowledge and other ecologies of knowledge can be linked. Although the assumptions of action research allow us to reflect on the emergence of epistemologies of the South and its relation with the acknowledgment of multiple knowledge beyond the academic knowledge imposed by scientific rationality, what we have observed is that this type of research still lacks more space for discussion, not only in the scientific circuits already consolidated and dominated by the hegemonic countries, such as the Action Research journal, published by Sage, but also of other scientific publishing spaces focused on the subject coming from emerging productions and perspectives of the periphery countries.

This discussion about action research is implicates directly in scientific assumptions, colonialism of knowledge and the idea of an invisible science, or rather, a science that is made invisible from the methodological assumptions of scientific rationality and geopolitics of knowledge, which renders other forms of production of multiple knowledge invisible. In the Global South, there is a need to review how science is evaluated, not only by its scientific value, impact and innovative aspects but also to include a concept that considers the social impact of science. /

Translated by Hernán Baeza

\section{BibliogRAPHIC REFERENCES}

Adelman, C. (1993). Kurt Lewin and the origins of action research. Educational Action Research, 1, 7-24. doi: $10.1080 / 0965079930010102$ 
Babini, D. (2011). Acceso abierto a la producción científica de América Latina y el Caribe: Identification of main institutions for regional integration strategies. Revista Iberoamericana de Ciencia Tecnología $y$ Sociedad, 6(17), 31-56. Retrieved from http://biblioteca.clacso.edu.ar/gsdl/collect/clacso/index/assoc/ D4662.dir/babini_EDITADO_FINAL.pdf

Bachmann, A. \& Parisotto, I. (2016). Extensão universitária e inovação social: estudo em uma universidade pública municipal. In Anais do Engema - Encontro Internacional sobre gestão empresarial e meio ambiente (pp. 1-15). São Paulo: Universidade de São Paulo.

Ballestrin, L. (2013). Decolonial turn and Latin America. Revista Brasileira de Ciência Política, 11, 89-117. doi: $10.1590 /$ So103-33522013000200004

Barbier, R. (1985). A pesquisa-ação na instituição educativa. Rio de Janeiro: Jorge Zahar.

Barbier, R. (2007). A pesquisa-ação. Brasília: Liber Livro Editora.

Castro-Gómez, S. \& Mendieta, E. (1998). Teorías sin disciplina: latinoamericanismo, poscolonialidad y globalización en debate. México: Miguel Ángel Porrúa.

Castro-Gómez, S. (2005). Ciências sociais, violência epistêmica e o problema da "invenção do outro". In E. Lander (Ed.), A colonialidade do saber: eurocentrismo e Ciências Sociais. Perspectivas latino-americanas (pp. 80-87). Buenos Aires: Colección Sur Sur.

Castro-Gómez, S. (2007). Decolonizar la universidad. La hybris del punto cero y el diálogo de saberes". In S. Castro-Gómez \& R. Grosfoguel (Eds.), El giro decolonial. Reflexiones para una diversidad epistémica más allá del capitalismo global (pp. 79-91). Bogotá: lesco-Pensar-Siglo del Hombre Editores.

Chauí, M. (2003). A universidade pública sob nova perspectiva. Revista brasileira de educação, 24, 5-15. Retrieved from http://www.scielo.br/pdf/rbedu/n24/n24ao2.pdf

Colaço, T. (2012). Novas perspectivas para a antropologia jurídica na América Latina: o direito e o pensamento decolonial. Florianópolis: Fundação Boiteux.

Colmenares, A. (2012). Investigación-acción participativa: una metodología integradora del conocimiento y la acción. Voces y Silencios, 3, 102-115. Retrieved from https://revistas.uniandes.edu.co/doi/pdf/10.18175/ vys3.1.2012.07

Dhanani, A. \& Jones, M. (2017). Editorial boards of accounting journals: gender diversity and internationalisation. Accounting, Auditing Q Accountability Journal, 30(5), 1008-1040. doi: 10.1108/ AAAJ-08-2014-1785

Etzkowitz, H. (2003). Innovation in innovation: the triple helix of university-industry government relations. Social Science Information, 42 (3), 293-337. doi: 10.1177/05390184030423002

Fals Borda, O. (1981). Aspectos teóricos da pesquisa participante: considerações sobre o significado e o papel da ciência na participação popular. In C. R. Brandão (Ed.), Pesquisa participante (pp. 42-62). São Paulo: Brasiliense.

Fals Borda, O. (2012). La praxis: ciencia y compromiso. In H. Armando. \& L. López. (Eds.), Ciencia, compromiso y cambio social. Textos de Orlando Fals Borda (pp. 147-205). Buenos Aires: El Colectivo.

Freire, P. (2005). Pedagogia do oprimido. Rio de Janeiro: Paz e Terra.

Forproex. (2012). Política Nacional de Extensão Universitária, do Fórum de Pró-Reitores de Extensão das Instituições Públicas de Educação Superior Brasileira (FORPROEX). Retrieved from http://proex.ufsc. $\mathrm{br} /$ files/2016/04/Pol\%C3\%ADtica-Nacional-de-Extens\%C3\%A3o-Universit\%C3\%Aıria-e-book.pdf 
Gajardo, M. (1985). Teoría y práctica de la educación popular. México: Organización de Estados Americanos.

Gomes, M. \& Pereira, F. E. (2015). Hélice tríplice: um ensaio teórico sobre a relação Universidade-EmpresaGoverno em busca da Inovação. International Journal of Knowledge Engineering and Management, 4(8), 136-155. Retrieved from http://incubadora.periodicos.ufsc.br/index.php/IJKEM/article/view/3309

Hall, B. \& Tandon, R. (2017). Decolonization of knowledge, epistemicide, participatory research and higher education. Research for All, 1, 06-19. doi: 10.18546/RFA.01.1.02

Lander, E. (2005). Ciências sociais: saberes coloniais eurocêntricos. In E. Lander (Ed.), A colonialidade do saber: eurocentrismo e Ciências Sociais. Perspectivas latino-americanas (pp. 8-23). Buenos Aires: Colección Sur.

Larivière, V., Haustein, S. \& Mongeon, P. (2015). The oligopoly of academic publishers in the digital era. PloS one, 10(6). doi: e0127502.

Levander, C. \& Mignolo, W. (2011). Introduction: the global south and world dis/order. The Global South, 5, 1-11. doi: 10.3998/jar.0521004.0067.202

Lindberg, M., Danilda, I. \& Torstensson, B.-M. (2012). Women resource centres: a creative knowledge environment of quadruple helix. Journal of the Knowledge Economy, 3(1), 36-52. doi: 10.1007/ 513132-011-0053-8

Lima, E. \& Silva, F. (2017). Pesquisa-ação na formação inicial de professores de matemática. Revista Saberes Docentes, 2, 1-22. Retrieved from http://www.revista.ajes.edu.br/index.php/RSD/article/view/212

Maldonado-Torres, N. (2008). A topologia do ser e a geopolítica do conhecimento. Modernidade, império e colonialidade. Revista Crítica de Ciências Sociais, 80, 71-114. Retrieved from https://journals.openedition. org/rccs/695

Martín-Barbero, J. (2014). "Tudo o que sabemos, sabemo-lo entre todos" "Aquela segunda oportunidade sobre a terra" - Algumas palavras para não faltar completamente. Revista Lusófona de Estudos Culturais, 2(1), 4-6. Retrieved from http://www.rlec.pt/index.php/rlec/article/view/51/44

Martins, M. (2015). A liberdade académica e os seus inimigos. Comunicação e Sociedade, 27, 405, 420. doi: $10.17231 /$ comsoc.27(2015).2109

Mata, I. (2014). Estudos pós-coloniais. Desconstruindo genealogias eurocêntricas. Civitas - Revista de Ciências Sociais, 14, 27-42. doi: 10.15448/1984-7289.2014.1.16185

Melo, A., Maia Filho, O. \& Chaves, H. (2016). Lewin e a pesquisa-ação: gênese, aplicação e finalidade. Factal, 28, 153-159. doi: 10.1590/1984-0292/1162

Meneses, M. P. (2008). Epistemologias do Sul. Revista Crítica de Ciências Sociais, 80, 5-10. Retrieved from http://journals.openedition.org/rccs/689

Merton, R. (1968). The Matthew effect in science. Science, 159(3810), 56-63. doi: 10.1126/science.159.3810.56

Merton, R. (1972). The sociology of science: theoretical and empirical investigations. Chicago: University of Chigaco Press.

Mignolo, W. (2008). Desobediência epistêmica: a opção descolonial e o significado de identidade em política. Cadernos de Letras da UFF - Dossiê: Literatura, língua e identidade, 34, 287-324. Retrieved from http://www.uff.br/cadernosdeletrasuff/34/traducao.pdf 
Mignolo, W. (2013). Geopolítica de la sensibilidad y del conocimiento. Sobre (de) colonialidad, pensamiento fronterizo y desobediencia epistémica. Revista de Filosofía, 74(2). Retrieved from http://eipcp.net/ transversal/o112/mignolo/es

Mugnaini, R. \& Strehl, L. (2008). Recuperação e impacto da produção científica na era Google: uma análise comparativa entre o Google Acadêmico e a Web of Science. Encontros Bibli: Revista Eletrônica de Biblioteconomia e Ciência da Informação (Vol. Especial), 92-105. doi: $10.5007 / 1518-2924.2008 \mathrm{v} 13$ nespipg2

Paini, L. \& Costa, L. (2016). A função social da universidade na contemporaneidade: algumas considerações. Eventos Pedagógicos, 7, 59-72. Retrieved from http://sinop.unemat.br/projetos/revista/index.php/ eventos/article/viewFile/2077/1701

Peruzzo, C. (2003). Da observação participante à pesquisa-ação em Comunicação: pressupostos epistemológicos e metodológicos. In Anais do XXVI Congresso Brasileiro de Ciências da Comunicação (pp. 1-23). Belo Horizonte: Intercom - Sociedade Brasileira de Estudos Interdisciplinares da Comunicação.

Peruzzo, C. (2016). Epistemologia e método da pesquisa-ação. Uma aproximação aos movimentos sociais e à comunicação. In Anais XXV Encontro Anual da Compós (pp. 1-22). Goiânia: Compós - Associação Nacional dos Programas de Pós-Graduação em Comunicação.

Resende, F. \& Thies, S. (2017). Temporalidades enredadas no Sul Global. Revista Contracampo, 36 (3), 1-19. doi: 10.22409/contracampo.v36iz.1095

Santos, B. D. S. (1995). Toward a new common sense: law, science and politics in paradigmatic transition. New York and London: Routledge.

Santos, B. D. S. (1999). Um discurso sobre as ciências. Porto: Afrontamento.

Santos, B. D. S. (2000). A crítica da razão indolente. São Paulo: Cortez.

Santos, B. D. S. (2007). Para além do pensamento abissal: das linhas globais a uma ecologia de saberes. Novos Estudos-CEBRAP, 79, 71-94. doi: 10.1590/S0101-33002007000300004

Santos, B. D. S. (2008). Renovar a teoria crítica e reinventar a emancipação social. São Paulo: Boitempo.

Sommer, R. (1999). Action research: from mental hospital reform in Saskatchewan to community building in California. Canadian Psychology/Psychologie Canadienne, 40(1), 47-55. doi: 10.1037/hoog2490

Souza da Silva, H., Rocha, E. \& Silva, W. (2003). Inovar para desenvolver: relação entre os atores universidade, empresa e governo. Examãpaku, 6(2), 1-14. doi: 10.18227/1983-9065ex.v6i2.2022

Thiollent, M. (2009). Metodologia da pesquisa-ação. São Paulo: Cortez.

Tripp, D. (2005). Pesquisa-ação: uma introdução metodológica. Educação e Pesquisa, 31(3), 443-466. Retrieved from http://www.scielo.br/pdf/ep/v3ın3/aogv3ın3.pdf

Vessuri, H., Guédon, J. \& Cetto, A. M. (2014). Excellence or quality? Impact of the current competition regime on science and scientific publishing in Latin America and its implications for development. Current Sociology, 62(5), 647-665. doi: 10.1177/0011392113512839

Wagner, C. \& Wong, S. (2011). Unseen science: representation of BRICs in global science. In 2011 Atlanta Conf on Science and Innovation Policy, Atlanta, September 15-17, 2011.

Williamson, G. \& Prosser, S. (2002). Action research: politics, ethics and participation. Journal of Advanced Nursing, 40(5), 587-593. doi: 10.1046/j.1365-2648.2002.02416.x 


\section{BIOGRAPHICAL NOTES}

Lumárya Souza de Sousa is a master's student in the Post-Graduation Program in Communication at the Fluminense Federal University. Member of the Laboratório de Experiências de Engajamento e Transformações da Audiência [Laboratory of Public Participation and Transformations Experiments] (Leeta). Assistant editor at Contracampo magazine. The theme of her undergoing thesis is the democratization of knowledge from the applied research project, Favelação, which is developed in Morro do Estado, in Niterói, RJ, Brazil. She has worked on knowledge democratization initiatives such as the Dose de Ciência celebrated on Dia D da Ciência [D-Day of Science], Pint of Science, among others.

E-mail: lumaryas@gmail.com

Address: Rua Aurelino Leal, 105, Ap 904 - Centro - Niterói / RJ - Brazil. Cep: 24020-110.

Thaiane Oliveira is a Professor in the Postgraduate Program in Communication at the Fluminense Federal University. Coordinator at the Laboratório de Investigação em Ciência, Inovação, Tecnologia e Educação [Research Laboratory for Science, Innovation, Technology and Education] (Cite-Lab), which houses the the Laboratório de Experiências de Engajamento e Transformações da Audiência [Laboratory of Public Participation and Transformations Experiments] (Leeta) and the o Núcleo de Estudos Estratégicos de Circulação e Políticas Científicas [Nucleus of Strategic Studies of Circulation and Science Policies] (Nepc).

E-mail: thaianeoliveira@id.uff.br

Address: Rua Cacilda Ouro, 783 - Itaipu - Niterói / RJ - Brazil. CEP: 24342-220.

* Submitted: 30.11 .2017

* Accepted: 15.03.2018 